WIDER Working Paper 2019/7

\title{
Innovation efforts in developing countries
}

The case of Vietnamese small and medium-sized enterprises

Son Thi Kim Le*

February 2019 
Abstract: The identification of potential innovation efforts plays an important role in evaluating the innovation process. The innovation efforts of firms in developing countries might be different to those of Western enterprises. This paper evaluates innovation processes in developing countries, especially the relationship between innovation efforts and outcomes. Instead of capturing only investment in research and development as in Western firms, the innovation efforts of firms in developing countries include investments in in-house research and development, technology acquisition, and other informal innovation activities. This research develops a mechanism to capture all innovation efforts based on firms' characteristics, market features, and business environment. A predicted value of innovation investment is created which is intended to capture observed and latent innovation efforts. The results show that predicted innovation investment triggers innovation outcomes (jointly, product and process innovation outcomes) in the context of Vietnamese small and medium-sized enterprises.

Keywords: developing countries, innovation effort, innovation input, innovation investment, innovation outputs,

JEL classification: C52, O31, O32, O57

Acknowledgements: I gratefully acknowledge the significant support received from the United Nations University World Institute for Development Economics Research (UNU-WIDER), where I worked as PhD intern for three months (March-June 2016), and their provision of the database on which this research is based.

*Toulouse School of Management Research, Université Toulouse, France, 1kson283@gmail.com.

This study has been prepared within the UNU-WIDER Visiting PhD Fellowship programme.

Copyright (C) The Author 2019

Information and requests: publications@wider.unu.edu

ISSN 1798-7237 ISBN 978-92-9256-641-8 https://doi.org/10.35188/UNU-WIDER/2019/641-8

Typescript prepared by Luke Finley.

The United Nations University World Institute for Development Economics Research provides economic analysis and policy advice with the aim of promoting sustainable and equitable development. The Institute began operations in 1985 in Helsinki, Finland, as the first research and training centre of the United Nations University. Today it is a unique blend of think tank, research institute, and UN agency — providing a range of services from policy advice to governments as well as freely available original research.

The Institute is funded through income from an endowment fund with additional contributions to its work programme from Finland, Sweden, and the United Kingdom as well as earmarked contributions for specific projects from a variety of donors.

Katajanokanlaituri 6 B, 00160 Helsinki, Finland

The views expressed in this paper are those of the author(s), and do not necessarily reflect the views of the Institute or the United Nations University, nor the programme/project donors. 
Researchers have long tried to theorize the performance of the innovation process. In the last few decades, many factors affecting the success of innovation strategies have been identified, including innovation efforts (Bogliacini, Perani, Pianta, \& Supino, 2012; Crespi \& Zuniga, 2012; Santos, Basso, Kimura, \& Kayo, 2014), resources (Van de Ven, 1986; Nooteboom, 1994; Eisenhardt \& Martin, 2000), and strategic choices (Talke, Salomo, \& Rost, 2010; Fréchet \& Goy, 2017). While identification of these factors has proved valuable to researchers, how the process can be modelled and, more generally, how the relationship between factors in the innovation process can be theorized remain in debate

One particular challenge has been to take into account the conditional nature of innovation output. Firms that are successful in innovation are those that have implemented certain specific strategies. To capture this situation, most researchers have developed structural models. While these models vary in content, they all follow a common logic: if a firm innovates, then a new stage begins in which the factors influencing the success of the strategy are considered. One particularly elaborate version of the model was proposed by Crépon, Duguet, and Mairesse (1998), hereafter called the CDM model, and has gained rapid popularity among innovation scholars in the last few years. Briefly, this framework suggests that innovation is a process that begins with the decision of whether to invest in research activities or not, and the degree to which a firm invests, which in turn creates innovation outputs.

Following this framework, models can identify potential innovation efforts and their effects on innovation outputs. Several prior works, especially those on developed countries, have applied the CDM framework to model the innovation process. Recent studies in developing countries have also replicated the model to evaluate firms' innovation. However, in different contexts, replication is not just about applying a framework. In fact, replicating this well-known framework, even partly, would not lead to any meaningful findings. The fundamental rationale is that the previous literature tends to confuse certain empirical and theoretical dimensions. This confusion is especially acute for innovation efforts and investments. Indeed, the models posit that firms' choice in innovation efforts is a central variable in explaining both innovation strategies and innovation outputs.

In this regard, Western firms' innovation investments can successfully be captured through inhouse research and development $(\mathrm{R} \& \mathrm{D})$ activities. However, the same does not hold in any way for developing countries. In such economies, formal in-house $\mathrm{R} \& \mathrm{D}$ is often non-existent, and external sources of technology/knowledge are more significant (Chudnovsky, López, \& Pupato, 2006). The presence of these specific innovation efforts induces one to question the close association between innovation investments and R\&D. Obviously, firms might develop innovation strategies without any $\mathrm{R} \& \mathrm{D}$ expenses, and as a consequence, researchers aiming to capture innovation efforts should develop richer measures or proxies for innovation activities.

The purpose of this study is to replicate and adapt a structural model of the innovation process in developing countries. Drawing inspiration from the CDM model, we build a model that accounts for the likelihood of innovation based on innovation efforts. In doing so, this econometric model estimates the channels linking investment in knowledge (in both formal and informal ways) to innovation outcomes (see Hall \& Mairesse, 2006). More precisely, we pay particular attention to the measurement issues which we believe are specific to developing countries. We propose to develop a new measure of innovation efforts and apply it to a sample of Vietnamese firms. In this case, investment includes investment in not only R\&D but also external knowledge input. We determine its influence on the probability of (1) product innovation; (2) process innovation; and 
(3) joint product and process innovation in small and medium-sized enterprises (SMEs) in the developing country of Vietnam.

Our study, then, appears as a replication study. Given the widespread use of structural models of innovation, a fundamental question was to assess to what extent the basic assumptions of the models held in Vietnam. Notwithstanding that, this kind of replication should be seen as replication in the loose or broad sense (Bettis, Helfat, \& Shaver, 2016): we rely on data which have not been explored before. As noted above, importing the structural model into the Vietnamese context, with its peculiar data structure, leads to a substantial need for adaptation of the model. Therefore, this paper is likely not only to support the robustness of previous models but also to extend them.

The remainder of the paper is organized as follows. Section 2 reviews innovation investments and extends the CDM approach to developing countries, while Section 3 describes the model specification. Section 4 introduces the data set and measurements. Section 5 describes the econometric results of the model. The discussion and conclusion are presented in Section 6.

\section{Literature review}

The purpose of this section is to give an overview of previous findings regarding classical structural models which explain innovation. These findings provide the basis which we will build upon for our own model specification.

\subsection{Transformation of innovation efforts into innovation outputs}

When developing a model of innovation, researchers have first to adhere to a stylized vision of the innovation process. While this process is undoubtedly very complex in the real world, the authors have to acknowledge the crucial importance of several elements. The key components may then be considered as derived from the CDM model in two fundamental stages. The first is a decision by firms about whether to allocate resources to innovation activities. This decision may be influenced by several factors at the firm level. If the firm decides to innovate, these factors will determine the level of innovation efforts, or innovation intensity. The second step is to assess the impact of this innovation intensity on innovation outputs. Figure 1 depicts how innovation efforts transform into innovation outputs.

The core of the transformation process is innovation efforts, or innovation inputs. In this theoretical framework, firms' investments in knowledge that are supposed to make firms more inclined to perform innovation activities should be recognized as innovation investment, or innovation inputs. For instance, investment in in-house knowledge sources such as R\&D expenditure is regarded as a common innovation input of Western firms. Given this framework, the empirical methodology is required to capture all the potential innovation efforts of the firms in the analysis. The problem is that innovation activities could appear in various forms, especially in developing countries. In such countries, firms often imitate or adapt external knowledge sources to develop their innovation outcomes rather than self-creating new knowledge (Chudnovsky et al., 2006). Therefore, several studies on firms in developing countries recognize external technology/knowledge as the source of innovation efforts. These innovation efforts are often measured through investments in machinery, equipment, software, and patents (e.g. Navarro, Llisterri \& Zuniga, 2010; Crespi \& Zuniga, 2012). In addition, many informal knowledge-creating activities associated with daily business activities might lead to the accumulation and development of internal knowledge sources outside the formal R\&D system. Such activities may have similar 
outcomes to innovation outputs; for instance, informal innovation activities can be by-products of learning-by-doing or bricolage processes. All these informal innovation activities must be captured as innovation inputs in a model of innovation processes in developing countries.

Figure 1: Innovation process according to the extended CDM framework

Decision to invest in innovation activities

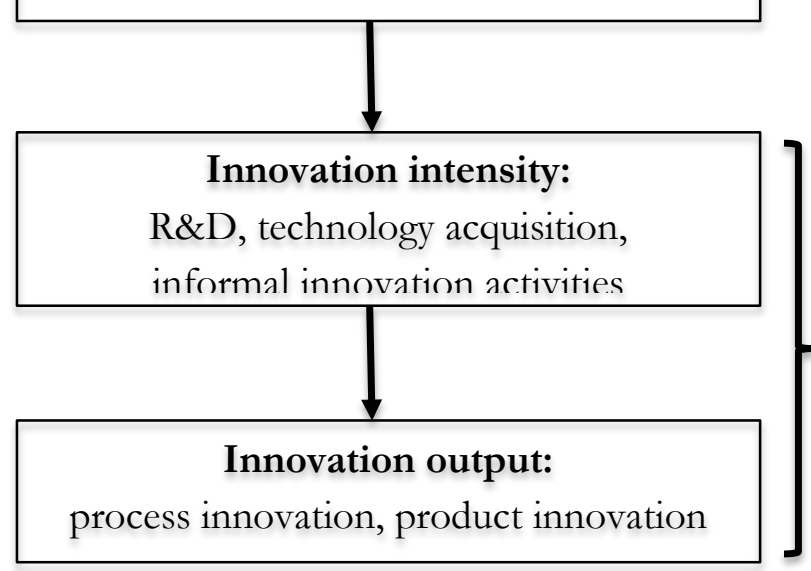

\section{Innovation process}

Source: adapted from Kemp, Folkeringa, De Jong, \& Wubben (2003), reproduced with permission from the copyright holder.

Innovation inputs, thus, can be captured in various forms of investment in knowledge, such as (1) investment in in-house knowledge sources (e.g. R\&D investment); (2) imitation of external technology/knowledge sources and technology/knowledge transfer (e.g. acquisition of equipment/machinery and disembodied technology) (Navarro et al., 2010); and (3) informal innovation activities that are not properly captured in survey questionnaires (Chudnovsky et al., 2006). Much previous research which has adapted the CDM framework has focused on such innovation inputs as the following.

\section{R\&D investment}

Many prior studies have recognized that $\mathrm{R} \& \mathrm{D}$ investment is a main driver of innovation (Crépon et al., 1998). R\&D, as defined by the Frascati Manual (OECD, 1993: 29), 'comprise[s] creative work undertaken on a systematic basis in order to increase the stock of knowledge and the use of this stock of knowledge to devise new applications'. R\&D, thus, is considered a main source of technical and knowledge changes that creates new knowledge or technology and new goods or processes (OCED, 2001). As a result, researchers have considered R\&D as the sole candidate to be a proxy for innovation efforts (Acs \& Audretsch, 1988; Crépon et al., 1998; Lööf \& Heshmati, 2001, 2002; Becheikh, Landry, \& Amara, 2006; Griffith, Huergo, Mairesse, \& Peters, 2006; Amara, Landry, Becheikh, \& Ouimet, 2008; Roper, Du, \& Love, 2008; Freeman \& Soete, 2009; Hall, Lotti, \& Mairesse, 2009; Marin, 2014; Baumann \& Kritikos, 2016; Garcia-Pozo, Marchante-Mera, \& Campos-Soria, 2018). However, some studies have failed to find a positive link between innovation inputs and outputs (e.g. Lööf, Heshmati, Asplund, \& Nåås, 2001; Benavente, 2006). The findings are mixed because researchers have adopted a narrow focus, examining only knowledge created through R\&D investment as innovation inputs and ignoring other important knowledge-creating activities that partly contribute to the success of innovation (Baldwin \& Hanel, 2003). For this reason, scholars suggest that $R \& D$ investment and related knowledge sources should be recognized as innovation inputs (Chudnovsky et al., 2006; Lööf \& Heshmati, 2006; Hall et al., 2009). 


\section{Innovation investment}

Considering innovation investment in the context of developing-country firms, there are varieties of investment in knowledge sources that are proven to have an impact on innovation outputs. For instance, these innovation investments include both $\mathrm{R} \& \mathrm{D}$ investment and technology acquisition, such as new equipment and machinery, in Argentina (Chudnovsky et al., 2006) and Chile (Alvarez, Bravo-Ortega, \& Navarro, 2010). Arza and López (2010) proposed different innovation inputs in Argentinian firms, including in-house knowledge sources (e.g. $\mathrm{R} \& \mathrm{D}$ investment, industrial engineering and design) and technologies from external sources (e.g. machinery, intangible technologies, and information and communication technologies). Based on a sample of six Latin American countries, Crespi and Zuniga (2012) suggested that innovation investments include investments in in-house knowledge such as $\mathrm{R} \& \mathrm{D}$ and investments in other knowledge sources such as design; installation of new machinery and equipment used for the implementation of innovations; industrial engineering; embodied and disembodied technology (e.g. capital and machinery, patents, trademark licensing, disclosure of know-how and computer-related and technical services); marketing; and training. In their study of SMEs, Hall et al. (2009) also confirmed the significance of technology/knowledge in acquired equipment and machinery as a significant source of innovation outputs. In summary, the innovation inputs of firms and SMEs in developing countries are derived mainly from two sources: internal knowledge-creating activities (R\&D investment) and external sources of knowledge.

\subsection{Research on innovation inputs in developing-country firms}

Many studies have explored the link between different types of innovation investment and the innovation outputs of firms in developing countries based on full or partial application of the CDM model. Such research has examined firms in Argentina (Chudnovsky et al., 2006; Arza \& López, 2010), Brazil (Correa, Sánchez, \& Singh, 2005; De Negri, Esteves, \& Freitas, 2007), Bulgaria (Stoevsky, 2005), Chile (Benavente 2006; Alvarez et al., 2010), China (Jefferson, Huamao, Xiaojing, \& Xiaoyun, 2006; Mairesse, Mohnen, Zhao, \& Zhen, 2012), Malaysia (Hegde \& Shapira 2007), Mexico (Pérez, Dutrénit, \& Barceinas, 2005), Pakistan (Wadho \& Chaudhry, 2018), and Latin America (Crespi \& Zuniga, 2012). Some studies have considered only R\&D to be a proxy for innovation efforts (see Benavente 2006; Jefferson et al., 2006; De Negri et al., 2007; Hegde \& Shapira 2007; Benavente \& Bravo, 2009; Mairesse et al., 2012; Wadho \& Chaudhry, 2018). Others have recognized R\&D and investments in other knowledge sources as innovation inputs (e.g. Correa et al., 2005; Stoevsky, 2005; Chudnovsky et al., 2006; Alvarez et al., 2010; Arza \& López, 2010; Crespi \& Zuniga, 2012). However, the findings regarding the significance of R\&D for fostering innovation outcomes differ between contexts. While most researchers found that a high level of investment in R\&D led to a higher probability of innovation outputs, some did not find that $R \& D$ had a positive influence. For instance, in the context of Chile, Alvarez et al. (2010) considered R\&D and other measures of innovation intensity (e.g. investment in machinery) as innovation inputs and found that $\mathrm{R} \& \mathrm{D}$ had a positive, significant role in innovation, but the results of Benavente (2006) and Benavente and Bravo (2009) do not support this finding. This inconsistency is due to differences in the innovation measurements; studies may use the predicted value of $R \& D$ intensity instead of observable $R \& D$ investment or may capture innovation investment via investment in machinery (which can be understood as an external knowledge source).

Some studies have tested the effects of innovation inputs (i.e. R\&D investment and external technology sources) separately (Correa et al., 2005; Stoevsky, 2005; Chudnovsky et al., 2006; Alvarez et al., 2010; Arza \& López, 2010), while others have examined the effect of innovation investment (combining both innovation inputs) on innovation outputs. Several studies found that R\&D investment increased the likelihood of product innovation whereas embodied technologies 
were relevant for explaining process innovation (Chudnovsky et al., 2006; Arza \& López, 2010; Vivarelli, 2014). Crespi and Zuniga (2012) proposed that innovation investment, defined as the combination of R\&D and technology acquisition, captured all knowledge sources involved in innovation activities. They found that greater innovation investment increased the probability of having at least one innovation output.

\subsection{Determinants of innovation efforts}

The original CDM model proposed that certain firm-level factors, such as firm size, market share, diversification, demand condition, and technological opportunities, influence firms' decision to engage in innovation activities and their outcomes. These factors, following Cohen and Levinthal (1989), could be determinants of research and innovation activities at the industry level. From these propositions, several studies have examined the factors that influence firms' innovation propensity and intensity in different contexts. We briefly discuss the determinants of innovation decisions and innovation intensity below.

First, numerous studies have examined the Schumpeterian hypothesis which argued a positive link between firm size and innovation efforts (Schumpeter, 1942). In addition, innovation surveys have shown that the probability of engaging in innovation activities is positively associated with firm size. The rationale for this phenomenon is that large firms have a greater ability to invest in expensive $\mathrm{R} \& \mathrm{D}$ activities, to diversify $\mathrm{R} \& \mathrm{D}$ projects, or to appropriate external knowledge spillovers (Crespi \& Zuniga, 2012).

Exporting activities are another determinant of innovation, because exporters do business in competitive global markets and thus are required to offer new or high-quality products to gain competitive advantages. Further, the 'learning-by-exporting' hypothesis is emphasized in studies analysing the link between innovation and exports (Crespi \& Zuniga, 2012; Salomon \& Shaver, 2005). This effect is expected to encourage firms' innovation efforts; due to the high level of competition in the global market, firms with a high degree of global market orientation are more likely to innovate than firms that act mainly in the domestic market.

Public support is also expected to help firms overcome the obstacles to innovation, such as financial sources and technology sources, because the main purpose of government funding is to encourage firms to be more innovative. The more public support firms receive, the more resources they can use to increase their level of innovation. Lack of finances also complements other obstacles to innovation to lower innovation investments (Mohnen \& Röller, 2005) because financial sources are critical for innovation, which often consumes considerable resources.

Firms with highly qualified human resources are likely to have a greater capability to adapt new knowledge, regardless of whether it is developed internally or externally (Huergo \& Moreno, 2011). In other words, human capital is expected to contribute to the success of innovation (Freel, 2005).

Finally, firms' perception of the global economic crisis is a determinant of innovation. As expected from the arguments of Schumpeter and Schumpeterian economics (Schumpeter, 1934, 1942), the crisis caused adverse effects on most economic agents but will not create loss in the long term. In fact, the crisis signals a change to a new economic cycle with business opportunities, and it is a chance for large, well-established firms to achieve potential benefits. Firms that perceive the global crisis as a positive signal might be ready to invest in innovation efforts to achieve a competitive advantage. 
Table 1: Literature on determinants of innovation efforts

\begin{tabular}{|c|c|c|}
\hline Factors & Main findings & Authors \\
\hline \multirow[t]{2}{*}{ Firm size } & $\begin{array}{l}\text { Affects innovation decision and increases } \\
\text { intensity of investment in both R\&D and } \\
\text { other innovation activities }\end{array}$ & $\begin{array}{l}\text { Lööf and Heshmati (2002); Janz, } \\
\text { Lööf, \& Peters (2003); Chudnovsky } \\
\text { et al. (2006); Criscuolo (2009); } \\
\text { Crespi and Zuniga (2012) }\end{array}$ \\
\hline & Independent of $R \& D$ investment intensity & $\begin{array}{l}\text { Crépon et al. (1998); Benavente } \\
\text { (2006); Griffith et al. (2006); Lööf } \\
\text { and Heshmati (2006); Hall et al. } \\
\text { (2009) }\end{array}$ \\
\hline \multirow[t]{2}{*}{$\begin{array}{l}\text { Competition } \\
\text { sources }\end{array}$} & $\begin{array}{l}\text { International competitiveness promotes R\&D } \\
\text { activities and influences the amount of } \\
\text { innovation investment }\end{array}$ & $\begin{array}{l}\text { Griffith et al. (2006); Mairesse and } \\
\text { Robin (2008) }\end{array}$ \\
\hline & $\begin{array}{l}\text { International competitiveness promotes R\&D } \\
\text { intensity }\end{array}$ & Hall et al. (2009) \\
\hline Export & $\begin{array}{l}\text { Export orientation has a positive impact on } \\
\text { innovation decision and intensity (mainly } \\
\text { R\&D) }\end{array}$ & $\begin{array}{l}\text { Lööf and Heshmati (2002); Janz et } \\
\text { al. (2003); Kemp et al. (2003); } \\
\text { Criscuolo (2009) }\end{array}$ \\
\hline \multirow[t]{2}{*}{ Public support } & $\begin{array}{l}\text { Affects the decision to invest in R\&D and the } \\
\text { intensity of R\&D investment }\end{array}$ & $\begin{array}{l}\text { Klomp and Van Leeuwen (2001); } \\
\text { Griffith et al. (2006); Roper et al. } \\
\text { (2008); Hall et al. (2009); Mairesse } \\
\text { et al. (2012) }\end{array}$ \\
\hline & $\begin{array}{l}\text { Affects the decision to invest in innovation } \\
\text { but not the intensity of innovation investment }\end{array}$ & Raffo, Lhuillery, \& Miotti (2008) \\
\hline Human capital & $\begin{array}{l}\text { Affects the decision to perform innovation } \\
\text { activities }\end{array}$ & Freel (2005) \\
\hline Lack of capital & Lowers innovation investment & Mohnen and Röller (2005) \\
\hline $\begin{array}{l}\text { Firms' perception } \\
\text { of the global } \\
\text { economic crisis }\end{array}$ & $\begin{array}{l}\text { If firms perceive the economic crisis as an } \\
\text { opportunity, they increase their investment } \\
\text { in innovation activities }\end{array}$ & Archibugi, Filippetti, \& Frenz (2013) \\
\hline
\end{tabular}

Source: Author's construction.

\section{$3 \quad$ Model specification}

The original CDM model established by Crépon et al. (1998) consists of three stages: (1) the firm's decision to invest in research activities and the intensity of investment; (2) the knowledge production function linking innovation investment (measured by $R \& D$ intensity) and innovation outputs; and (3) the output production function determining the impact of knowledge produced on productivity/performance. In our application of the CDM framework, we focus on the mechanism of translating innovation efforts/inputs into innovation outputs, and we thus dismiss the last stage of the original model (i.e. the output production function). As a result, our model includes only two stages, with two equations in stage 1 and one in stage 2.

Much previous research adopting the CDM approach simply replicated the developed-country agenda, analysing R\&D investment as a main proxy for innovation and capturing innovation outputs via patents (see Crépon et al., 1998) or share of innovative sales (see Janz et al., 2003; Mairesse et al., 2005; Jefferson et al., 2006, Lööf \& Heshmati, 2006; Roper et al., 2008). However, these measurements could be idiosyncratic to specific contexts. For instance, in the context of developing countries, external technology sources (such as embedded technology acquired through the purchase of machinery, equipment, licensing, or patents) are more important than inhouse $\mathrm{R} \& \mathrm{D}$. Therefore, introducing new products to the market might not be the result only of 
R\&D activities. In such a case, formal R\&D investments could not capture the actual scope of the innovation efforts of firms in developing countries. Further, developing countries are often characterized by weak intellectual property rights, so firms in these countries are less likely to file patents for innovations (Wadho \& Chaudhry, 2018). As a result, patent data seems to be irrelevant for these firms. Another common innovation output is innovative sales, defined as the part of firms' sales derived from innovation activities. However, the innovation efforts of developingcountry firms are not completely captured, and in relation to such firms it may be difficult to distinguish between sales from innovation and sales from non-innovation activities. Due to these disparities between developed and developing countries, the extended CDM framework needs to be adjusted to fit the context examined here.

Figure 2: A part of the CDM model (innovation inputs and outputs)

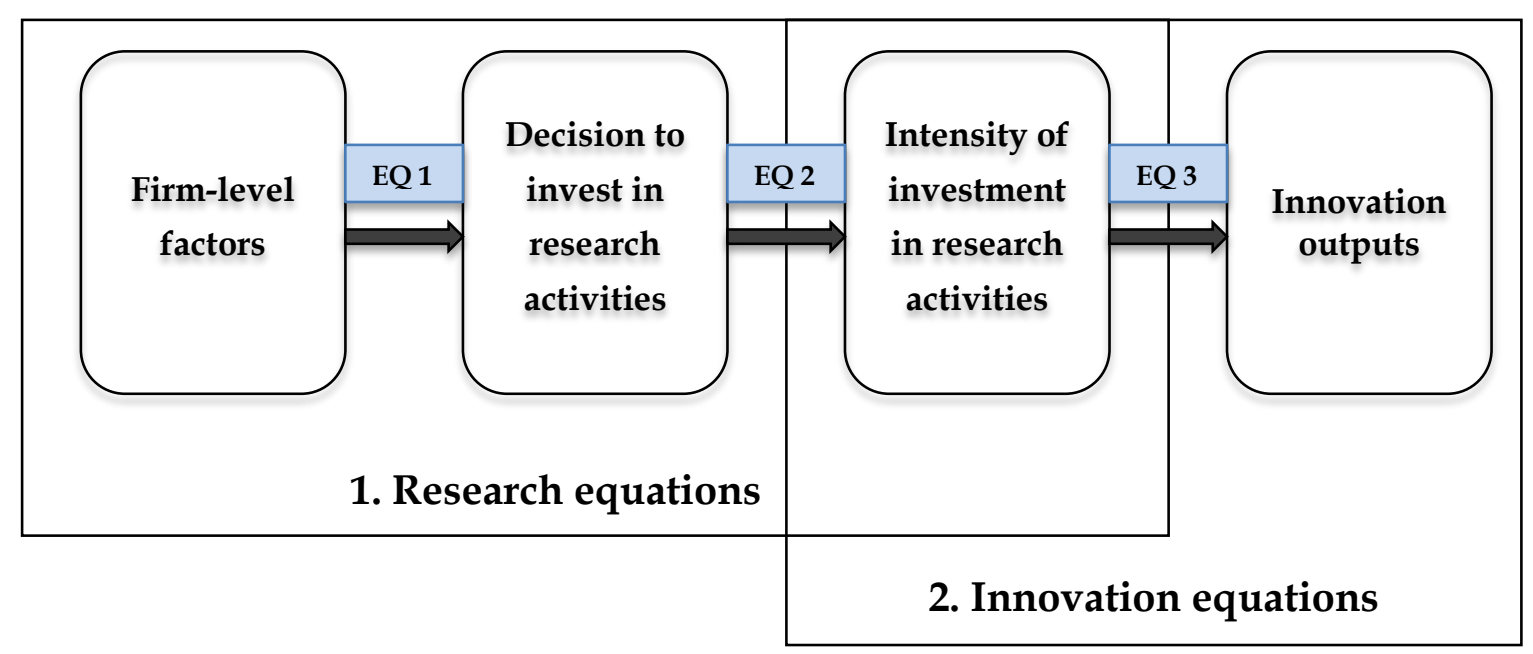

Source: Author's construction based on Crépon et al. (1998).

\subsection{Propensity to invest in innovation and intensity of innovation investment}

The first stage of the model involves identification of firms' innovation decision and innovation investment intensity. We believe that the adjustment in this step for developing-country firms is the broadening of innovation measurement. Rather than just considering R\&D investment as a unique innovation input, a new measurement of innovation inputs should be able to include all the innovation efforts characterizing developing-country firms. Firms operating in developing countries are often considered 'technological followers' (Gurca \& Ravishankar, 2016), as they tend to invest in importing external sources of technology/knowledge rather than in creating new technologies internally. These external knowledge/technology sources provide a path to more innovative efforts (Griffith, Redding, \& Van Reenen, 2004). Absorbing external knowledge and technology resources via advanced equipment and machinery might be considered an innovation effort because this process enhances firms' ability to assimilate and apply external knowledge for commercial purposes or to broaden their internal knowledge sources (Matusik \& Heeley, 2005). In summary, there are two main types of innovation activities-those involving internal production of innovation and those drawing on external knowledge sources-that should be recognized as innovation activities performed by firms in developing countries.

This stage includes two equations: one determining a firm's propensity to invest in innovation (i.e. the selection equation) and one determining the intensity of investment in innovation. The Heckman selection equation (Heckman, 1979) estimates the probability that firms will engage in innovation investment. Given enterprises that engage in innovation investment, the second equation estimates the intensity of innovation investment. 


$$
\begin{aligned}
& r_{1 i}=1\left(r_{1 i}^{*}>0\right) \text { where } r_{1 i}^{*}=b_{1 i} X_{1 i}+e_{1 i} \\
& r_{2 i}=r_{2 i}^{*}=b_{2 i} X_{2 i}+e_{2 i} \text { if } r_{1 i}^{*}>0 \text { and zero otherwise }
\end{aligned}
$$

Supposing that $\mathrm{r}_{1 \mathrm{i}}^{*}$ is an unobserved variable representing a firm's decision to invest in innovation and $r_{2 i}^{*}$ is the unobserved level of a firm's investment in innovation, $r_{1 i}$ and $r_{2 i}$ are their observable counterparts in the two equations. In the above expression, $\mathrm{X}_{1 \mathrm{i}}, \mathrm{X}_{2 \mathrm{i}}, \mathrm{b}_{1 \mathrm{i}}$, and $\mathrm{b}_{2 \mathrm{i}}$ are the vectors of explanatory variables and the corresponding parameters that explain the effects of different determinants on the decision to engage in innovation investment and the level of innovation investment. In addition, $\mathrm{e}_{1 \mathrm{i}}$ and $\mathrm{e}_{2 \mathrm{i}}$ are the error terms, which have a mean of zero, constant variance, and are not associated with the independent variables. Assuming that the errors terms of Equations (1) and (2) are bivariate normal with zero mean and variance equal unity, the two equations above can be estimated using the maximum likelihood. In the literature, this model is sometimes referred to as a Heckman selection model (Heckman, 1979) or Tobit type II model (Amemiya, 1984). ${ }^{1}$

Several studies have mentioned a problem in Equation (2): selection bias arises when only an innovation sample is used and firms are not randomly drawn from a larger population (Hall et al., 2009). Another problem is endogeneity that may be due to a technological shock (i.e. a new invention or technological breakthrough might improve the probability of observing an innovation) and thus lead to innovation outputs. This can be overcome by including in Equation (2) the predicted probability of engaging in innovation from Equation (1), the corresponding Mills ratio, and their squares and interaction terms.

To overcome these problems, before estimating Equation (2), a non-parametric test should be performed to test for selection bias in the innovation investment intensity equation (Hall et al., 2009). The first step is to develop a probit model in which positive innovative investment is regressed using firm characteristics, including firm size, source of competition, public assistance, export activities, human capital, innovation constraints (e.g. lack of capital and adverse consequences of economic crisis), and control variables (e.g. firm age, industry, location, time). From the results of this step, the predicted probability of positive innovative investment and the corresponding Mills ratio are determined for each firm in the sample. According to Hall et al. (2009), a simple linear (OLS) for innovation intensity is estimated which includes the predicted probabilities from the innovation decision equation, the Mills' ratio, their squares, and their interaction terms. The significance of these probability terms proves the presence of selectivity bias. The results reported in Table 5 (Column 2a) indicate that these probability terms are insignificant, either singly or jointly. This implies that there is no selectivity bias in the model. After this step, a predicted value of innovation investment intensity is captured for each observation. In the next step, a simple linear regression using OLS tests the linkage between predicted innovation investment intensity and innovation outputs without the need to correct for selectivity bias.

\subsection{Innovation output}

\footnotetext{
${ }^{1}$ Robustness checks were performed. Before estimating the first two equations of the model, a conditional fixed effects logit (maximum likelihood) and linear fixed effects estimator were applied to the probability of positive innovation investment and innovation investment intensity based on the panel data. However, the results of the Hausman test proved that the panel estimator is not different from the pooled estimators used to estimate the first equation (rho $=0)$ and the random effects model is better than the fixed effects model for the second equation $(\mathrm{p}=$ $<0.05)$, thus rejecting the null hypothesis.
} 
The innovation output stage assesses the impact of innovation inputs and other factors related to them. It also must be adjusted to fit the context of developing countries. The original CDM model estimates the link between innovation inputs and outputs only for innovative firms, not for all firms. This strategy might not be effective for small firms or developing-country firms for various reasons, as follows. These firms, due to their small size and lack of resources, tend to engage in informal knowledge production activities based on sources other than $\mathrm{R} \& \mathrm{D}$, such as learning-bydoing (Chudnovsky et al., 2006) or bricolage processes (Baker \& Nelson, 2005; Senyard, Baker, Steffens, \& Davidsson, 2014). Such activities are difficult to estimate or capture, even if they are very relevant. Thus, although they might lead to innovation outcomes, firms do not report them as innovation activities. The estimation of innovation outputs based only on investment in observable innovation activities might be biased because it might fail to take into account the effect of informal innovation activities. Therefore, we apply an estimation strategy that uses the predicted value of all innovation investments (observable and latent) to replace one that considers only visible innovation efforts (see Hall et al., 2009; Alvarez et al., 2010; Crespi \& Zuniga, 2012).

The second adjustment that must be made to the CDM model is related to proxy innovation output. The most common proxies are patents and the share of innovative sales. However, these proxies might not be applicable to small firms or developing-country firms. Instead, following Griffith et al. (2006), several studies on firms in developing countries consider only the existence of product or process innovation as innovation outputs. Critics of this measurement claim that it cannot clarify the level or scope of innovation output, but if information about patents and innovative sales does not exist or is difficult to capture, this indicator might be a reasonable solution. Some research has estimated the effect of innovation efforts on each kind of innovation (product and process innovation) separately (see Chudnovsky et al., 2006), whereas others use one indicator to represent all innovation outputs (see Crespi \& Zuniga, 2012). In this research, we diverge from previous studies by capturing all the possible innovation outcomes that a firm can achieve from product and process innovation. In other words, we believe that firms may introduce only product innovation, only process innovation, or product and process innovation jointly.

To model all available innovation outcomes, this research applies the multinomial logit model (MNL), which is estimated using the standard maximum likelihood estimation procedure. For this MNL model, the base category/comparison group is non-innovators, including firms without any innovation outcomes. The model can be estimated as follows:

$$
g_{i}^{*}=a_{0}+a_{1} r_{2 i}+a_{3 i} X_{3 i}+e_{3 i}
$$

where $\mathrm{g}_{\mathrm{i}}^{*}$ is an innovation output measure that cannot be observed completely. The observed model is described by the following:

$\mathrm{g}=0$ if the firm does not have any innovation output;

$\mathrm{g}=1$ if the firm introduces both product and process innovation;

$\mathrm{g}=2$ if the firm introduces only product innovation; and

$\mathrm{g}=3$ if the firm introduces only process innovation.

Moreover, $\mathrm{r}_{2 \mathrm{i}}$ is the latent innovation investment effort proxied by the predicted value of innovation investment intensity determined by Equation (2); $\mathrm{a}_{0}$ is the corresponding vector of unknown parameters; $\mathrm{X}_{3 \mathrm{i}}$ is the set of explanatory variables, including firm size, human capital, capital shortage, firms' perception of the economic crisis, ten dummies for firms' location according to province, 23 industry dummies of manufacturing firms (two-digit International 
Standard Industrial Classification), and a time dummy (equal to 1 for firms included in the survey in 2013 and 0 otherwise) (see Table 2). Further, $a_{3 \mathrm{i}}$ is the corresponding vector of unknown parameters, while $\mathrm{e}_{3 \mathrm{i}}$ is the error term that allows for the existence of correlation between them and is assumed to be $i i d \sim \mathrm{N}\left(0 ; \boldsymbol{\sigma}_{\mathrm{u}}\right)$.

Table 2: Variable definitions

\begin{tabular}{|c|c|}
\hline Variable & Definition \\
\hline Innovation decision & $\begin{array}{l}\text { Dummy equal to } 1 \text { if the firm reported positive investment in technology } \\
\text { acquisition (equipment/machinery) and R\&D over period t }\end{array}$ \\
\hline Innovation investment intensity & $\begin{array}{l}\text { Total investment in technology acquisition (equipment/machinery) and R\&D } \\
\text { per employee at the end of period } t \text { (in a logarithm) }\end{array}$ \\
\hline $\begin{array}{l}\text { Innovation outcomes } \\
\text { - Non-innovator } \\
\text { - Product-process innovator } \\
\text { - Product innovator } \\
\text { - Process innovator }\end{array}$ & $\begin{array}{l}\text { Equal to } 1 \text { if the firm has no innovation outputs } \\
\text { Equal to } 2 \text { if the firm introduces both product and process innovation } \\
\text { Equal to } 3 \text { if the firm introduces only product innovation } \\
\text { Equal to } 4 \text { if the firm introduces only process innovation }\end{array}$ \\
\hline $\begin{array}{l}\text { Competition from domestic } \\
\text { enterprises }\end{array}$ & Dummy equal to 1 if the firm's main competition is domestic enterprises \\
\hline $\begin{array}{l}\text { Competition from legal } \\
\text { imports/foreign enterprises }\end{array}$ & $\begin{array}{l}\text { Dummy equal to } 1 \text { if the firm's main competition is legal imports/foreign } \\
\text { enterprises }\end{array}$ \\
\hline $\begin{array}{l}\text { Firm size class } \\
\text { - Micro } \\
\text { - Small } \\
\text { - Medium }\end{array}$ & $\begin{array}{l}\text { Equal to } 1 \text { for micro firms (fewer than } 10 \text { employees) } \\
\text { Equal to } 2 \text { for small firms (between } 10 \text { and } 50 \text { employees) } \\
\text { Equal to } 3 \text { for medium-sized firms (between } 50 \text { and } 300 \text { employees) }\end{array}$ \\
\hline Export & Dummy equal to 1 if the firm is an exporter \\
\hline Government assistance & $\begin{array}{l}\text { Dummy equal to } 1 \text { if the firm received any financial or technical assistance } \\
\text { from the Vietnamese government }\end{array}$ \\
\hline Age & The firm's age in a logarithm \\
\hline Human capital & $\begin{array}{l}\text { Average proportion of employees with a university degree or who are } \\
\text { engineers and administrators }\end{array}$ \\
\hline $\begin{array}{l}\text { Firms' perception of the } \\
\text { economic crisis }\end{array}$ & $\begin{array}{l}\text { Dummy equal to } 1 \text { if the firm experienced adverse consequences due to } \\
\text { the recent international economic crisis }\end{array}$ \\
\hline Lack of capital & $\begin{array}{l}\text { Dummy equal to } 1 \text { if the firm reported lack of capital as a major constraint } \\
\text { on growth }\end{array}$ \\
\hline Time & Dummy equal to 1 if the firm was included in survey in 2013 \\
\hline
\end{tabular}

Source: Author's construction.

Innovation investment includes R\&D expenditure and technology acquisition. Predicted innovation investment intensity is included in Equation (3) to account for innovation outputs captured from all innovation efforts (including both observable and latent efforts). A predicted value instead of an actual one is used to instrument innovation efforts in Equation (3) in order to solve the simultaneity problem (more generally, the endogeneity problem) between innovation efforts and the expectation of innovative success. Endogeneity can be explained as the unobserved heterogeneity at the firm level, including unobservable management quality and entrepreneurship based on firms' characteristics and activities that might affect innovation investment and outcomes. 


\subsection{Data}

This research utilizes data from an SME survey conducted in Vietnam (CIEM, DoE, ILSSA, and UNU-WIDER, 2008; 2010; 2012; 2014). It is part of a long-running panel survey that has been conducted every two years since 2005. Most firms were interviewed across all years. Just over 2,500 small and medium-sized non-state enterprises operating in the manufacturing sector were interviewed in the cities of Ha Noi, Hai Phong, and Ho Chi Minh City (HCMC) and the provinces of Ha Tay, Phu Tho, Nghe An, Quang Nam, Khanh Hoa, Lam Dong, and Long An. The sample includes information about the enterprises that have been interviewed since 2005 and new enterprises that were added to replace those that exited the survey. The survey is carried out by the United Nations University World Institute for Development Economics Research (UNUWIDER) in collaboration with the Institute of Labour Science and Social Affairs (ILSSA) of the Ministry of Labour, Invalids and Social Affairs (MOLISA), the Department of Economics (DoE) of the University of Copenhagen, and the Central Institute of Economic Management (CIEM).

The surveyed enterprises are distributed across approximately 18 sectors, including food processing, metal product fabrication, and wood product manufacturing. Enterprises are classified according to the current World Bank definition; micro-enterprises are defined as having up to ten employees, small-scale enterprises have up to 50 employees, medium-sized enterprises have up to 300 employees, and large enterprises have more than 300 employees. The database includes firms with many forms of ownership: household establishment/business, private (sole proprietorship), partnership, collective/co-operative, limited liability company, joint stock company with state capital, joint stock company without state capital, joint venture with foreign capital, state enterprise (central), and state enterprise (local).

The questionnaire used in the survey includes more than 130 questions about firms' general characteristics; history; production characteristics and technology; sales structure; indirect costs, raw materials, and services; investments, assets, liabilities, and credit; fees, taxes, and informal costs; employment; environment; network; and economic constraints and potentials. The survey consists of face-to-face interviews conducted in June, July, and August every two years. Firms that participated in the previous survey are re-interviewed. The data set obtained from the surveys in 2011 and 2013 excludes firms with incomplete information. The final sample includes 4,845 observations, 891 of which involve positive innovative investment.

Each survey covers the two years immediately prior (2009-2010, 2011-2012), and the survey questionnaires are almost identical. This paper focuses on manufacturing SMEs, which represent $98 \%$ of the sample, and imposes a threshold of 300 employees in line with the World Bank's definition of SMEs. The data from the two surveys mentioned above were merged, and firms with incomplete information were excluded. The results of the Vietnamese SME survey in 2013 show a decline in innovation activities. The proportion of firms that had improved existing products decreased from $41 \%$ to $38 \%$ from 2009 to 2011, and continued to decline in next two-year period of this survey (from 2011 to 2013). The results showed that few firms carried out new product innovation during the period 2011-2013. In particular, none of the enterprises performed new product innovation in 2011 or continued it in 2013. More than $86 \%$ of the firms had not introduced any new products in the considered survey period, and a large share of firms (1,074 out of 1,988 ) did not enhance their current products in 2011 or 2013. In total, $22 \%$ of the firms which engaged in innovation activities related to improvement products in 2011 continued to improve their products in 2013. 


\subsection{Measurements}

\section{Dependent variables}

Innovation decision: This variable is a dummy that equals 1 if the firm reports positive innovation investment (R\&D and technology acquisition) and 0 otherwise (Chudnovsky et al., 2006; Hall et al., 2009; Crespi \& Zuniga, 2012).

Innovation investment. This variable is the actual amount of investment in $\mathrm{R} \& \mathrm{D}$ and equipment/machinery per employee (in logarithm), which is often referred to as innovation input (Chudnovsky et al., 2006; Lööf \& Heshmati, 2006; Hall et al., 2009; Crespi \& Zuniga, 2012).

Innovation outcomes: This is a categorical variable that captures innovation outcomes (e.g. Chudnovsky et al., 2006), including (1) non-innovators; (2) product innovators; (3) process innovators; and (4) product and process innovators. This variable is different from that used by Hall et al. (2009), which captured the probability of product innovation and process innovation separately.

\section{Independent variables}

Predicted innovation investment. This variable refers to 'real' innovation investment, including both formal and informal innovation investment (e.g. Crespi \& Zuniga, 2012). This predicted value is captured after determining the factors that drive the innovation decision and innovation investment intensity (Hall et al., 2009).

Firm size: Schumpeter's theory (Schumpeter, 1942) about the link between firm size and innovation efforts is tested using a category variable for firm size according to the firm size classification in which the number of employees determines the size of the enterprise. Some research has captured firm size by the number of employees, such as the studies of Löof and Heshmati (2006) and Chudnovsky et al. (2006), but this study captures firm size using a dummy for each firm size group, including micro, small, and medium. Micro-enterprises are considered to be the reference group in the model (e.g. Hall et al., 2009; Mairesse et al., 2012).

Competition level: Because the data are available from the Vietnamese SME survey, this paper examines firms' perceptions of competition to determine the main source of their competition and its effect on their probability of deciding to innovate and of investing in innovation. According to the survey, competition arises from state, non-state, and legal import/foreign enterprises. This research uses two dummy variables to represent the source of Vietnamese SMEs' competition, including domestic enterprises (both state and non-state firms) and legal import/foreign enterprises (e.g. Griffith et al., 2006; Hall et al., 2009).

Export activities: The binary variable of being an exporter (direct and indirect) is included to capture whether export activities promote investment in general, and investment in R\&D activities in particular (e.g. Chudnovsky et al., 2006; Mairesse et al., 2012), and, in turn, innovation outputs.

Government support. Over the years, the central policy of the Vietnamese government has been to promote SMEs by providing public financial and technical assistance. Like several prior studies, this research intends to examine the effectiveness of this policy in stimulating innovation investment propensity and intensity by including a binary variable that captures the probability of having received government assistance (e.g. Roper et al., 2008; Hall et al., 2009) 
Human capital: The qualifications of the labour force are measured by the share of employees who have a university degree or are engineers and administrators (e.g. Janz et al., 2003).

Lack of capital: This research examines shortage of capital, using a dummy if the firm reports lack of capital as a major constraint of growth (e.g. Savignac, 2008).

Firms' perception of global economic crisis: This research uses a dummy variable equal to 1 if the firm experiences adverse consequences due to the recent financial crisis and 0 otherwise.

\section{Control variables}

The first control variable is firm age, which is represented by the log of the firm's age. Region category variables (including ten provinces ranging from the north to the south and from urban to rural areas in Vietnam) are used to control for different regions when estimating the effect on innovation investment and decision. This study also controls for unobserved industry characteristics using the industry categories in the General Statistics Office (GSO) product list given in the Economic Sectors 2-digit ISIC manual (GSO, 2015; 2016; 2017). Lastly, this study intends to examine the determinants of innovation decision and investment over two periods following the recent economic crisis (2009-2010 and 2011-2012). Thus, it includes a time dummy to prevent the error estimation caused by the latent effects due to changes in the economic context.

\section{$5 \quad$ Econometric results}

\subsection{Summary statistics}

Table 3 reports the summary statistics for the variables used in the paper. In total, $18.4 \%$ of firms in the sample engage in innovation investment. The quantity of firms with positive innovation investment decreased from $20.6 \%$ in 2011 to $16.1 \%$ in 2013 . Specifically, the number of firms without innovation investment increased from 1,927 firms in 2011 to 2,027 firms in 2013, but the proportion of firms with positive investment declined. Table 3 indicates that the average innovation investment decreased, but not as much as the change in the rate of firms with positive innovation investment. Furthermore, the percentage of process innovators increased from $56.3 \%$ of firms in 2011 to $66.7 \%$ of firms in 2013. Conversely, the number of firms with innovation outcomes (only product innovation or both product and process innovation) decreased over the two survey periods. These statistics are validated by the decreasing percentage of firms with innovation investment.

Table 3 shows that 46.3\% and nearly 40\% of firms were medium-sized in 2011 and 2013, respectively. These rates are higher than those for micro and small enterprises. Moreover, the number of all firms with innovation investment reduced over the period of the two surveys. The number of firms facing competition from foreign competitors (85\% in 2011 and $86.8 \%$ in 2013) is more than twice as high as the number of firms competing with domestic firms $(34.7 \%$ in 2011 and $36.9 \%$ in 2013) Furthermore, the number of firms that perceived competition from two sources increased slightly, which may reflect an increase in competitive pressure for the Vietnamese firms in the sample. 
Table 3: Summary statistics

\begin{tabular}{|c|c|c|c|c|c|c|}
\hline \multirow[t]{2}{*}{ Variables } & \multicolumn{2}{|c|}{ Total } & \multicolumn{2}{|c|}{2011} & \multicolumn{2}{|c|}{2013} \\
\hline & Mean & SD & Mean & SD & Mean & SD \\
\hline Innovator & 0.184 & 0.387 & 0.206 & 0.405 & 0.161 & 0.368 \\
\hline Innovation investment intensity & 7.432 & 1.535 & 7.478 & 1.460 & 7.373 & 1.627 \\
\hline Competition from domestic enterprises & 0.859 & 0.348 & 0.849 & 0.358 & 0.868 & 0.339 \\
\hline $\begin{array}{l}\text { Competition from legal import/foreign } \\
\text { enterprises }\end{array}$ & 0.359 & 0.480 & 0.347 & 0.476 & 0.369 & 0.483 \\
\hline Innovation outcomes & 0.131 & 0.338 & 0.141 & 0.348 & 0.124 & 0.330 \\
\hline - Non-innovator & 0.445 & 0.498 & 0.451 & 0.499 & 0.429 & 0.498 \\
\hline - Product-process innovator & 0.207 & 0.405 & 0.207 & 0.405 & 0.206 & 0.404 \\
\hline $\begin{array}{l}\text { - Product innovator } \\
\text { - Process innovator }\end{array}$ & 0.606 & 0.490 & 0.563 & 0.499 & 0.667 & 0.475 \\
\hline $\begin{array}{l}\text { Firm size class } \\
\text { - Micro firms ( }<=10 \text { employees) }\end{array}$ & 0.145 & 0.352 & 0.161 & 0.368 & 0.130 & 0.336 \\
\hline - Small firms (11-50 employees) & 0.259 & 0.438 & 0.293 & 0.455 & 0.220 & 0.415 \\
\hline - Medium firms (51-300 employees) & 0.431 & 0.496 & 0.463 & 0.500 & 0.398 & 0.492 \\
\hline Export & 0.061 & 0.240 & 0.060 & 0.238 & 0.062 & 0.241 \\
\hline Government assistance & 0.130 & 0.337 & 0.146 & 0.353 & 0.115 & 0.319 \\
\hline Firm age & 1.074 & 0.286 & 1.038 & 0.293 & 1.110 & 0.274 \\
\hline Human capital & 0.035 & 0.068 & 0.034 & 0.066 & 0.036 & 0.070 \\
\hline Firms' perception of the economic crisis & 0.650 & 0.477 & 0.618 & 0.486 & 0.681 & 0.466 \\
\hline Lack of capital & 0.403 & 0.490 & 0.472 & 0.499 & 0.334 & 0.472 \\
\hline No of observations & & 4,845 & & 2,428 & & 2,417 \\
\hline
\end{tabular}

Source: Author's construction.

On average, only $6.1 \%$ of firms in the sample were exporters (6.0\% in 2011 and $6.2 \%$ in 2013), and $13.0 \%$ of SMEs received some assistance from the government. The latter proportion decreased between 2009 and 2013. From 2011 to 2013, the average proportion of employees who had a university degree or were engineers or administrators was very low $(3.4 \%$ in 2011 and 3.6\% in 2013). There was an increase in the number of firms stating that the crisis adversely affected their business (from $61.8 \%$ in 2011 to $68.1 \%$ in 2013). In addition, a lack of capital was the most important barrier to introducing a new product for $47.2 \%$ of firms in 2011 and $33.4 \%$ of firms in 2013.

\subsection{Tests for multinomial logit model}

Several tests are used for the MNL, including tests of independent variables, tests for combining dependent categories, and independence of irrelevant alternatives (IIA) tests. The first one is used to test that all coefficients associated with independent variables are simultaneously equal to zero. The second tests whether independent variables differ between two outcomes and whether two outcomes can be combined. The IIA test includes the Hausman test, or the LR test, which was proposed by McFadden (1976) and improved by Small and Hsiao (1985), to test the assumption of independence of irrelevant alternatives. MNL estimations are based on the assumption of identical independent error terms, and violation of this assumption results in biased estimates. 
Thus, the MNL model is inappropriate. The results of the first test (either the LR test or the Wald test) prove that the effects of each variable, except firm age and the dummy for capital shortage, are significant at the 0.05 level. The second test (LR test and Wald test) concerning the ability to combine outcomes proves that no categories of innovation outcomes should be combined.

Table 4: Test of IIA assumption

\begin{tabular}{lrrr}
\hline Hausman test & & & \\
\hline & Chi2 & df & P>chi2 \\
Non-innovator & 0.000 & 9 & 1.000 \\
Product-process innovator & 0.000 & 8 & 1.000 \\
Product innovator & 6.120 & 12 & 0.910 \\
Process innovator & 0.000 & 2 & 1.000 \\
Small-Hsiao test & & 120 & 1.000 \\
Non-innovator & -6290.933 & 120 & 1.000 \\
Product-process innovator & -731.019 & 120 & 1.000 \\
Product innovator & -2139.172 & 120 & 1.000 \\
Process innovator & -492.365 & & \\
\hline
\end{tabular}

Note: $N=4,845$.

Source: Author's construction.

Lastly, there was an inconsistency in the results of the IIA test (see Table 4); the Hausman test revealed two negative chi-squared and two insignificant test statistics. Negative test statistics are common (Long \& Freese, 2006: 244-45) and indicate that the IIA property is not violated (Hausman \& McFadden 1984: 1,226). Similarly, the Small-Hsiao test indicates that all the test statistics are insignificant, showing further evidence that the IIA property holds.

Readers should be reminded that innovation is assumed to depend on the choice of innovative investment and that this research is based on a cross-sectional sample for two reasons. First, the results of the Hausman test for Equations (1) and (2) show that random effects estimation is more appropriate than fixed effects estimation and the LR test for rho $=0$, proving that the panel estimator is not different for the pooled estimator. The second reason is related to the timing of the survey, in which innovation investment and innovation decision are measured over the twoyear period of each survey, and thus a direct causal link between innovation investment and innovation cannot be assumed (Hall, Lotti, \& Mairesse, 2013). Therefore, the results of this research should be considered as associations rather than causal links.

\subsection{Econometric results}

\section{Propensity and intensity of innovation investment}

Table 5 reports the results of the probit model, including the potential determinants identified above. Column (1) in Table 5 indicates the impact of firm characteristics on the probability of Vietnamese SMEs engaging in innovation efforts by reporting the marginal effects of all variables. Column (2a) reports the results of a non-parametric test for selectivity bias in innovation investment intensity (Equation (2)). The estimated innovation investment intensity is reported in Column (2b). 
Table 5: Innovation investment propensity and intensity

\begin{tabular}{|c|c|c|c|}
\hline & (1) & (2a) & (2b) \\
\hline Variables & $\begin{array}{l}\text { Innovation } \\
\text { investment } \\
\text { propensity }\end{array}$ & $\begin{array}{l}\text { Innovation investment } \\
\text { per employee }\end{array}$ & $\begin{array}{c}\text { Innovation } \\
\text { investment intensity }\end{array}$ \\
\hline \multirow[t]{2}{*}{ Competition domestic } & $0.0670^{\star \star \star}$ & $-3,102^{\star \star \star}$ & -0.129 \\
\hline & $(0.0176)$ & $(1,124)$ & $(0.188)$ \\
\hline \multirow[t]{2}{*}{ Competition foreign } & $-0.0240^{\star *}$ & $1,125^{\star \star \star}$ & $0.235^{\star \star}$ \\
\hline & $(0.0122)$ & $(417.5)$ & $(0.118)$ \\
\hline \multirow[t]{2}{*}{ Firm size—small firm } & $0.0964^{\star \star \star}$ & $-4,306^{\star \star \star}$ & 0.0124 \\
\hline & $(0.0166)$ & $(1,543)$ & $(0.128)$ \\
\hline \multirow[t]{2}{*}{ Firm size—-medium firm } & $0.253^{\star \star \star}$ & $-9,625^{\star \star \star}$ & $-0.354^{*}$ \\
\hline & $(0.0336)$ & $(3,393)$ & $(0.192)$ \\
\hline \multirow[t]{2}{*}{ Export } & 0.0365 & $-1,052$ & $0.604^{\star \star \star}$ \\
\hline & $(0.0222)$ & (693.2) & $(0.193)$ \\
\hline \multirow[t]{2}{*}{ Government assistance } & $0.0452^{\star \star \star}$ & $-1,725^{\star \star}$ & -0.183 \\
\hline & $(0.0148)$ & (778.0) & $(0.133)$ \\
\hline \multirow[t]{2}{*}{ Firm age (log) } & $-0.120^{\star \star \star}$ & $5,701^{\star \star \star}$ & $-0.304^{\star}$ \\
\hline & (0.0193) & $(2,008)$ & $(0.180)$ \\
\hline \multirow[t]{2}{*}{ Human capital } & 0.0745 & & \\
\hline & $(0.0887)$ & & \\
\hline \multirow{2}{*}{$\begin{array}{l}\text { Firms' perception of the } \\
\text { economic crisis }\end{array}$} & $0.0321^{\star \star \star}$ & $-1,581^{\star \star \star}$ & 0.0182 \\
\hline & $(0.0124)$ & (555.3) & $(0.126)$ \\
\hline \multirow[t]{2}{*}{ Lack of capital } & $0.0569 * \star \star$ & $-2,389 * *$ & $0.218^{\star \star}$ \\
\hline & $(0.0111)$ & (951.1) & $(0.110)$ \\
\hline \multirow[t]{2}{*}{ Time dummy } & $-0.0226^{\star *}$ & $1,141 * \star *$ & -0.141 \\
\hline & $(0.0107)$ & $(392.9)$ & $(0.108)$ \\
\hline \multirow[t]{2}{*}{ Inverse Mill's ratio } & & 60,085 & \\
\hline & & $(50,033)$ & \\
\hline \multirow{2}{*}{$\begin{array}{l}\text { Predict probability (innovative } \\
\text { investment }>0 \text { ) }\end{array}$} & & $-115,506$ & \\
\hline & & $(110,661)$ & \\
\hline \multirow[t]{2}{*}{ Square inverse Mill's ratio } & & $-12,364$ & \\
\hline & & $(8,220)$ & \\
\hline \multirow{2}{*}{$\begin{array}{l}\text { Square predict probability } \\
\text { (innovative investment }>0 \text { ) }\end{array}$} & & 215,691 & \\
\hline & & $(166,068)$ & \\
\hline \multirow{2}{*}{$\begin{array}{l}\text { Inverse Mill's ratio * predict } \\
\text { probability }\end{array}$} & & 168,060 & \\
\hline & & $(133,973)$ & \\
\hline \multirow[t]{2}{*}{ Constant } & & $-90,465$ & $7.481 * \star \star$ \\
\hline & & $(76,607)$ & $(0.313)$ \\
\hline Industry and location dummies & & Yes & Yes \\
\hline Observations & 4,845 & 4,845 & 891 \\
\hline
\end{tabular}

Notes: Standard errors in parentheses; ${ }^{\star \star *} p<0.01,{ }^{\star *} p<0.05,{ }^{*} p<0.1$.

Source: Author's construction. 
The results in Table 5 confirm that competition in the domestic market is positively associated with only innovation propensity $(\beta=.067, p<.01)$ and has no impact on innovation investment intensity. Foreign markets are negative and significant in the propensity equation but positive and significant in the intensity equation $(\beta=-.024, p<.05$, and $\beta=.235, p<.05$, respectively). The coefficients of firm size (including small and medium size) are positive and significant $(\beta=.096$, $p<.01$, and $\beta=.253, p<.01$, respectively). The dummy for export activities is positively associated with only innovation investment intensity $(\beta=.604, p<.01)$. The coefficient of public support is positively related to the propensity for innovation investment $(\beta=.045, p<.01)$. The coefficient of the dummy variable for adverse impacts of the economic crisis is positive and significant in the propensity equation $(\beta=.032, p<.01)$. Lastly, lack of capital is positive and significant in both the propensity and the intensity equations $(\beta=.057, p<.01$, and $\beta=.218$, $p<.05$, respectively).

\section{Innovation output}

The results of the multinomial logistic regression are presented in Table 6. This study explains the innovation outcomes, distinguishing between non-innovators, product-process innovators, product innovators, and process innovators, with non-innovators serving as the base category. Table 6 reports three econometric results of each outcome- the coefficient, marginal effects, and relative risk ratios - which are the coefficients in exponential form and indicate how the risk of the outcome falling in the comparison group changes with the variable in question compared with the risk of the outcome falling in the reference group. A ratio greater than (less than) one indicates a higher (lower) probability of having both product and process innovation or only product innovation or process innovation over non-innovation.

Regarding the equation for innovation outcomes, the predicted innovation investment is positively associated with the probability of joint product and process innovation $(\beta=.726, p<.05)$, and the coefficients of this variable for the probability of introducing only product or process innovation are insignificant. SMEs are positively related to all innovation outcomes, but the effect for medium-sized firms seems to be higher than for small firms. For instance, the probability of joint product and process innovation in medium firms is two times higher than for small firms ( $\beta=1.866, p<.01$, and $\beta=.948, p<.01$, respectively). Similarly, human capital positively influences two innovation outcomes: product innovators and product-process innovators $(\beta=4.563, p<.01$, and $\beta=2.424, p<.01$, respectively). Firms that experienced adverse consequences of the global economic crisis are more likely to engage in product and productprocess innovation $(\beta=.615, p<.01$, and $\beta=.387, p<.01$, respectively). Finally, lack of capital does not trigger innovation outcomes, except for process innovation $(\beta=.572, p<.01)$.

\section{Discussion and contribution}

\subsection{Discussion}

The purpose of this study was to adapt the structural models of innovation to Vietnam. Replicative in nature, this work responds to the call for replication studies in strategic management (Bettis et al., 2016). Many studies published in top management journals actually fail the replication test, especially due to the lack of details about data (Bergh, Sharp, Aguinis, \& Li, 2017). As a consequence, the cumulative process of knowledge-building may be hampered. In our case, we show that structural models might be developed in the context of Vietnam. Our own approach may also be replicated itself, due to the fact that the data are publicly available. Besides, most importantly, our study also contributes to extending knowledge. 


\section{Transformation of potential innovation efforts into innovation outcomes}

The most important finding of this study is that innovation investment has a significant impact on the creation of innovation outcomes. As mentioned previously, this research proposes some adjustments to the innovation measurement and estimation methods compared with the original CDM model to ensure that all the typical innovation efforts of small firms in developing countries are captured. Basically, innovation efforts are derived from the activities or characteristics of firms that are supposed to make them more inclined to engage in innovation activities. Based on this, innovation efforts and innovation investment are captured in this research through $R \& D$, technology acquisition, and other unobservable innovation activities.

As expected, both formal and informal innovation efforts lead to certain types of innovation output. More precisely, predicted innovation investment increases the probability of joint product and process innovation. This finding clearly shows that significant innovation efforts lead to a higher probability of innovation outputs, but not necessarily to only product or process innovation (see Figure 3). This finding aligns with the results of Chudnovsky et al. (2006), who examined another developing country, Argentina. However, we use a different method of categorizing innovation outputs: we define three categories of innovation outcomes-(1) only product innovation, (2) only process innovation, and (3) joint product and process innovation-whereas Chudnovsky et al. (2006) divided innovation outputs into product innovation and process innovation. Using a similar estimation strategy and innovation measurement, Crespi and Zuniga (2012) found that innovation investment was significantly associated with innovation outputs in six developing countries in Latin America. However, we use a different method of capturing innovation outputs to Crespi and Zuniga (2012), who defined innovation output as the introduction of product or process innovation. Distinguishing between several types of innovation output is expected to more accurately capture the effect of innovation investment on each possible innovation outcome of a firm. 
Table 6: Determinants of innovation outcomes

\begin{tabular}{|c|c|c|c|c|c|c|c|c|c|}
\hline \multirow[b]{2}{*}{ Variable } & \multicolumn{3}{|c|}{ Product-process innovation } & \multicolumn{3}{|c|}{ Product innovation only } & \multicolumn{3}{|c|}{ Process innovation only } \\
\hline & Coefficient & $\begin{array}{c}\text { Marginal } \\
\text { effect }\end{array}$ & $\begin{array}{l}\text { Relative } \\
\text { risk ratio }\end{array}$ & Coefficient & $\begin{array}{l}\text { Marginal } \\
\text { effect }\end{array}$ & $\begin{array}{l}\text { Relative } \\
\text { risk ratio }\end{array}$ & Coefficient & $\begin{array}{l}\text { Marginal } \\
\text { effect }\end{array}$ & $\begin{array}{l}\text { Relative } \\
\text { risk ratio }\end{array}$ \\
\hline Predict innovation investment & $\begin{array}{l}0.726 \star \star \\
(0.293)\end{array}$ & $\begin{array}{l}0.035^{\star *} \\
(0.015)\end{array}$ & $\begin{array}{l}2.067^{\star *} \\
(0.605)\end{array}$ & $\begin{array}{c}0.279 \\
(0.208)\end{array}$ & $\begin{array}{c}0.033 \\
(0.0304)\end{array}$ & $\begin{array}{c}1.322 \\
(0.275)\end{array}$ & $\begin{array}{l}-0.437 \\
(0.470)\end{array}$ & $\begin{array}{c}-0.018 \\
(0.0148)\end{array}$ & $\begin{array}{c}0.646 \\
(0.304)\end{array}$ \\
\hline Firm size-small firm & $\begin{array}{c}0.948^{\star \star *} \\
(0.159)\end{array}$ & $\begin{array}{l}0.048^{\star \star \star} \\
(0.0097)\end{array}$ & $\begin{array}{c}2.580^{\star \star \star *} \\
(0.410)\end{array}$ & $\begin{array}{l}0.201^{\star} \\
(0.103)\end{array}$ & $\begin{array}{c}0.001 \\
(0.0155)\end{array}$ & $\begin{array}{l}1.222^{\star} \\
(0.126)\end{array}$ & $\begin{array}{c}0.608^{\star \star \star} \\
(0.234)\end{array}$ & $\begin{array}{c}0.018^{*} \\
(0.0093)\end{array}$ & $\begin{array}{c}1.838^{\star \star *} \\
(0.430)\end{array}$ \\
\hline Firm size-medium firm & $\begin{array}{c}1.866^{\star \star \star} \\
(0.215)\end{array}$ & $\begin{array}{l}0.122^{\star \star *} \\
(0.0224)\end{array}$ & $\begin{array}{c}6.464^{\star \star *} \\
(1.392)\end{array}$ & $\begin{array}{c}0.573^{\star \star \star} \\
(0.175)\end{array}$ & $\begin{array}{c}0.031 \\
(0.027)\end{array}$ & $\begin{array}{c}1.773^{\star \star * *} \\
(0.310)\end{array}$ & $\begin{array}{c}1.278^{\star \star \star} \\
(0.325)\end{array}$ & $\begin{array}{c}0.042^{\star *} \\
(0.0188)\end{array}$ & $\begin{array}{c}3.587^{\star \star *} \\
(1.165)\end{array}$ \\
\hline Firm age & $\begin{array}{l}-0.218 \\
(0.259)\end{array}$ & $\begin{array}{c}-0.013 \\
(0.0135)\end{array}$ & $\begin{array}{c}0.804 \\
(0.209)\end{array}$ & $\begin{array}{c}0.149 \\
(0.156)\end{array}$ & $\begin{array}{c}0.029 \\
(0.0231)\end{array}$ & $\begin{array}{c}1.160 \\
(0.181)\end{array}$ & $\begin{array}{l}-0.375 \\
(0.327)\end{array}$ & $\begin{array}{c}-0.012 \\
(0.0104)\end{array}$ & $\begin{array}{c}0.687 \\
(0.225)\end{array}$ \\
\hline Human capital & $\begin{array}{c}4.563^{\star \star *} \\
(0.856)\end{array}$ & $\begin{array}{c}0.202^{\star * *} \\
(0.044)\end{array}$ & $\begin{array}{c}95.898^{* * *} \\
(82.109)\end{array}$ & $\begin{array}{c}2.424^{\star \star *} \\
(0.616)\end{array}$ & $\begin{array}{l}0.294^{\star * *} \\
(0.0896)\end{array}$ & $\begin{array}{c}11.293^{\star * *} \\
(6.953)\end{array}$ & $\begin{array}{l}-0.811 \\
(1.565)\end{array}$ & $\begin{array}{l}-0.054 \\
(0.049)\end{array}$ & $\begin{array}{c}0.444 \\
(0.695)\end{array}$ \\
\hline $\begin{array}{l}\text { Firms' perception of economic } \\
\text { crisis }\end{array}$ & $\begin{array}{c}0.615^{\star \star \star} \\
(0.162)\end{array}$ & $\begin{array}{l}0.025^{\star \star \star} \\
(0.0085)\end{array}$ & $\begin{array}{c}1.850^{\star \star *} \\
(0.300)\end{array}$ & $\begin{array}{c}0.387^{\star \star *} \\
(0.088)\end{array}$ & $\begin{array}{l}0.046^{\star \star \star} \\
(0.0131)\end{array}$ & $\begin{array}{l}1.473^{\star \star \star} \\
(0.130)\end{array}$ & $\begin{array}{c}0.310 \\
(0.190)\end{array}$ & $\begin{array}{c}0.006 \\
(0.006)\end{array}$ & $\begin{array}{l}1.364 \\
(0.260)\end{array}$ \\
\hline Lack of capital & $\begin{array}{c}0.084 \\
(0.153)\end{array}$ & $\begin{array}{c}0.002 \\
(0.044)\end{array}$ & $\begin{array}{l}1.088 \\
(0.167)\end{array}$ & $\begin{array}{l}0.055 \\
(0.094)\end{array}$ & $\begin{array}{c}0.003 \\
(0.0139)\end{array}$ & $\begin{array}{l}1.056 \\
(0.099)\end{array}$ & $\begin{array}{l}0.572^{\star \star \star} \\
(0.203)\end{array}$ & $\begin{array}{l}0.018^{\star \star \star} \\
(0.0065)\end{array}$ & $\begin{array}{l}1.772^{\star \star \star} \\
(0.359)\end{array}$ \\
\hline Time & $\begin{array}{l}-1.323^{\star \star \star} \\
(0.147)\end{array}$ & $\begin{array}{l}-0.045^{\star \star *} \\
(0.0075)\end{array}$ & $\begin{array}{c}0.266^{\star \star *} \\
(0.039)\end{array}$ & $\begin{array}{l}-1.310^{* * *} \\
(0.085)\end{array}$ & $\begin{array}{l}-0.171^{\star \star *} \\
(0.0119)\end{array}$ & $\begin{array}{l}0.270 \star \star \star \\
(0.023)\end{array}$ & $\begin{array}{l}-0.696^{\star * *} \\
(0.180)\end{array}$ & $\begin{array}{l}-0.01^{*} \\
(0.0054)\end{array}$ & $\begin{array}{l}0.499 * * * \\
(0.090)\end{array}$ \\
\hline Industry and location dummies & Yes & & & & & & & & \\
\hline No. of observations & 4,845 & & & & & & & & \\
\hline LL & $-3,717.8015$ & & & & & & & & \\
\hline $\mathrm{Chi}^{2}$ & $1,150.36$ & & & & & & & & \\
\hline $\mathrm{p}$ & 0.00000 & & & & & & & & \\
\hline$R^{2} \_p$ & 0.1340 & & & & & & & & \\
\hline
\end{tabular}

Notes: Base category: non-innovator; standard errors in parentheses; ${ }^{\star \star \star} p<0.01,{ }^{\star \star} p<0.05,{ }^{*} p<0.1$.

Source: Author's construction. 


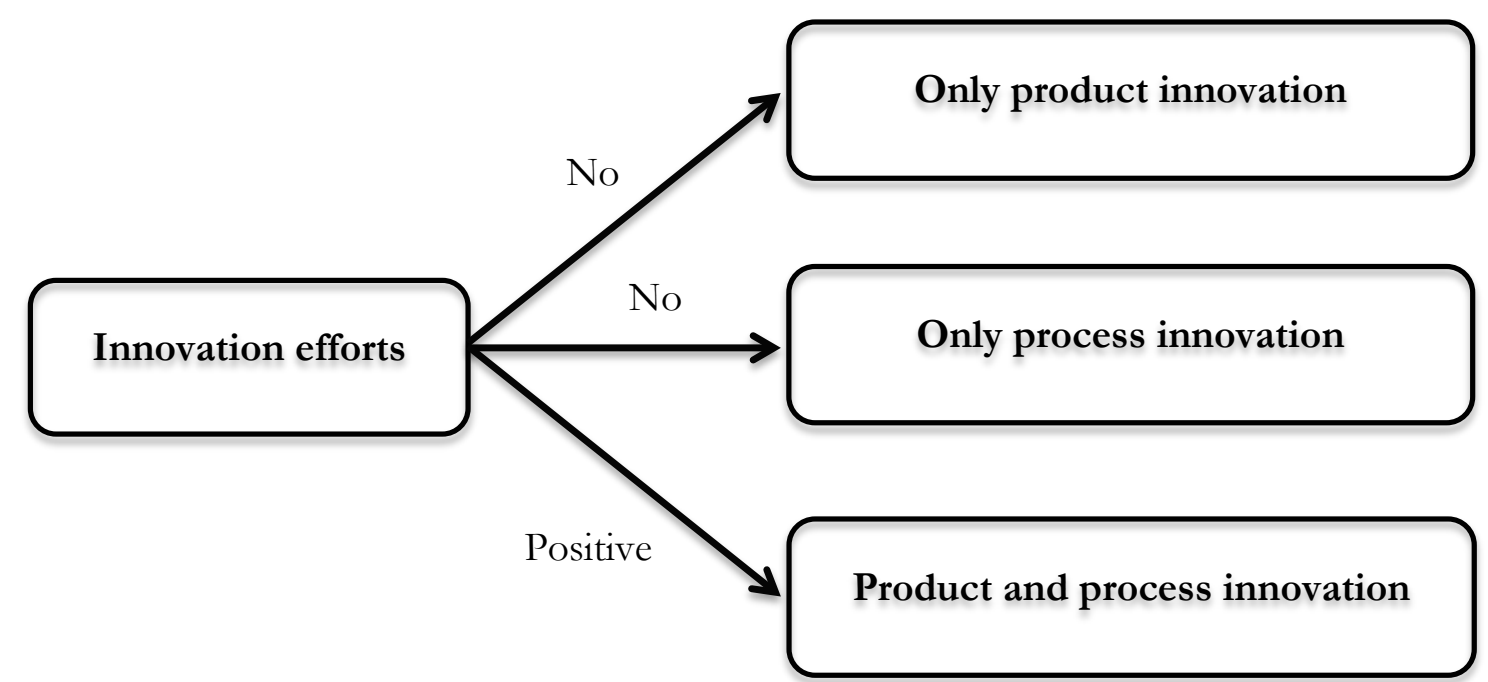

Source: Author's construction.

\section{Determinants of innovation efforts}

This research identifies the determinants of the likelihood of engaging in innovation investment (referred to here as positive innovation investment) and the intensity of this investment (log of total investment in R\&D activities and technology acquisition per employee). We followed the argument of Crespi and Zuniga (2012: 16): all firms engage in innovation activities (latent or observable), 'but only some of them are engaging in a sufficient amount for it to be report[ed]'. Thus, we capture the determinants of all firms' innovation decisions and then test for the significance of these determinants for the innovation investment of only those firms that decide to engage in innovation activities. The findings regarding the expected determinants are presented below.

We find that larger firms tend to be more innovative than smaller ones. This result aligns with Schumpeter's (1942) theory about the link between firm size and innovation efforts. Large firms have more advantages in terms of resources than small ones, and thus they are more likely to innovate based on investment in expensive $R \& D$ activities and diversifying $R \& D$ projects. At the same time, large-size advantages also support them in a better appropriation of external knowledge spillovers (Crespi \& Zuniga, 2012). This result is also found in some developing countries (e.g. six Latin American countries; Crespi \& Zuniga, 2012). Additionally, some research has proven the significance of firm size (e.g. in Argentina: Chudnovsky et al., 2006; Arza \& López, 2010). However, in line with some studies performed in both developed and developing countries, this research found that firm size does not affect the intensity of innovation efforts (referred to here as innovation investment). It is thus unsurprising that the findings regarding the relationship between firm size and innovation investment intensity are mixed.

Other results are as follows. First, firms competing with legal import/foreign enterprises have lower innovation investment propensity but higher innovation investment intensity. Second, engaging in export activities is not a determinant of innovative investment motivation, in line with the findings of Chudnovsky et al. (2006). This result is contrary to the findings of Salomon and Shaver (2005), who examined firms in Spain; Hahn (2010), who examined firms in Korea; and 
Tsou, Liu, Hammitt, and Wang (2008), who examined firms in Taiwan. These studies found that exporting firms operating in the international market have, on average, a higher probability of engaging in innovation activities. A critical justification of these results is that the fiercely competitive environment of global markets often requires firms to offer innovative products or services to gain competitive advantages.

Third, government assistance is positively associated with innovation investment propensity but independent of innovation investment intensity. This result aligns with Raffo et al. (2008) but contradicts the findings of Hall et al. (2009) and Mairesse et al. (2012). The purpose of the public support is to encourage firms to be more innovative, but the level of innovation depends not only on the presence of subsidies but also on type and amount of support. The mixed results might be due to differences in policy between countries. For instance, public assistance for innovation in Vietnam often focuses only on innovation generation, such as financial and technological support. The policy on encouraging innovation generation through collaboration with other firms or the public research sector, universities, or public research organizations is still limited. In addition, the limited role of the Vietnamese government in setting up the rules and regulations to support innovation protection is also a primary barrier to the innovation process in Vietnam.

Fourth, having highly qualified human resources is likely to raise the capability to adapt new knowledge developed either internally or externally, and thus to support the ability to engage with innovation activities. However, this research found that highly qualified human resources are not associated with innovation investment propensity. This finding is similar to the results of Huergo and Moreno (2011), who measured innovation input with only R\&D investment.

Fifth, surprisingly, lack of capital increases the likelihood of engaging in innovation and innovation intensity. The literature on innovation often shows that financial shortages are a barrier to innovation. The contradictory findings of this study can be explained by the fact that firms that pursue innovation projects (which often require extensive resources) are more likely to perceive a lack of capital than non-innovating firms (Iammarino, 2005).

Lastly, the global crisis is an obstacle to innovation and restricts firms' investment in innovation (which is often risky). This study found that firms that perceive the crisis as an opportunity for business are more likely to invest in innovation activities than others. The economic crisis causes business opportunities to become riskier, and therefore results in a reduction of firms' willingness to participate in long-term business activities. In that context, cutting down expenditure and postponing investment decisions is an appropriate strategy for firms in the process of recession after the economic crisis. A significant drop in investment in innovation was noted after the financial crisis in the autumn of 2008 in Europe (Filippetti \& Archibugi, 2011) and in Latin American countries (Paunov, 2012). However, as Schumpeter and the Schumpeterian literature suggest should be the case, although the crisis causes adverse effects on most economic agents, it will not create only losers in the long term. The crisis, in long run, signals a change to a new economic cycle, with the surging of new business opportunities. This is also a chance for firms to obtain potential benefits in the near future. Firms that perceive the global crisis as a positive signal might be ready to invest in innovation to gain competitive advantages.

\subsection{Contribution}

This paper analyses the innovation activities of Vietnamese SMEs to evaluate the innovation process in developing countries. It applies the CDM framework to determine the potential innovation efforts of firms in developing countries. Consistent with prior literature, this research found that new measurement of innovation investment could significantly explain the innovation outputs of Vietnamese SMEs. On one hand, this finding contributes to literature on innovation 
by introducing a new indicator of innovation efforts to represent firms in developing countries. On the other hand, the findings improve the understanding of the adapted CDM framework for evaluating the innovation process. This research replicates the framework and applies it to firms in developing countries, but it makes some adjustments to fit the typical features of such firms, including new measurement and estimation strategies for innovation efforts. The findings provide evidence on the competence of the CDM framework in evaluating the innovation process, especially the link between innovation efforts and innovation outcomes.

The significance of innovation inputs in Vietnamese SMEs confirms that the innovation efforts of firms in developing countries are different to those of Western firms. Innovation investment in developing countries is captured in different ways; for instance, innovation inputs may include inhouse R\&D investment and technology acquisition separately or jointly. The significance of innovation investment (the predicted value of R\&D and technology acquisition) in this study contributes to the enlargement of innovation investment measurement in developing countries.

Importantly, these findings show that, although firms in developing countries (especially SMEs) have a low level of investment in $\mathrm{R} \& \mathrm{D}$, they do not necessarily find it difficult to be innovative. Thus, these firms should consider R\&D activities to be only a part of innovation activities, not unique innovation indicators. Additionally, external knowledge sources should be recognized as important innovation inputs. The innovation outputs of these firms may include latent informal investment in knowledge that is not reported as observed innovation investment.

Consistent with the literature, the features of the innovation process in developing countries cause it to not follow the common innovation process of firms in developed countries. Instead, the innovation process of firms in developing countries needs to have its own design that fits the context of these countries. This research contributes to the literature on the difference in innovation generated in developed and developing regions.

\subsection{Limitations}

Similarly to Hall et al. (2009), we applied dummy variables for innovation success and other firm characteristics, such as size, competition sources, export activities, growth constraints, and public support. Thus, this research is unable to determine the effect on innovation outputs of firm size, competition, level of export or government assistance, or severity of barriers to innovation. In addition, this paper features a limited data set. The Vietnamese SME survey does not focus on innovation, so, for example, the data on firms' investments do not distinguish between investments intended for innovation and those intended for non-innovation activities. Therefore, unlike prior research, this research cannot analyse the impact on innovation outputs of investment made solely for innovation purposes. 


\section{References}

Acs, Z. J., \& Audretsch, D. B. (1988). Innovation in large and small firms: An empirical analysis. The American Economic Review, 78(4), 678-690.

Alvarez, R., Bravo-Ortega, C., \& Navarro, L. (2010). Innovation, R\&D investment and productivity in Chile. IDB Working Paper Series IDB-WP-190. Washington, DC: InterAmerican Development Bank (IDB).

Amara, N., Landry, R., Becheikh, N., \& Ouimet, M. (2008). Learning and novelty of innovation in established manufacturing SMEs. Technovation, 28(7), 450-463.

Amemiya, T. (1984). Tobit models: A survey. Journal of Econometrics, 24(1-2), 3-61.

Archibugi, D., Filippetti, A., \& Frenz, M. (2013). The impact of the economic crisis on innovation: Evidence from Europe. Technological Forecasting and Social Change, 80(7), 1247-1260.

Arza, V., \& López, A. (2010). Innovation and productivity in the Argentine manufacturing sector. IDB Working Paper Series IDB-WP-187. Washington, DC: Inter-American Development Bank (IDB).

Baker, T., \& Nelson, R. E. (2005). Creating something from nothing: Resource construction through entrepreneurial bricolage. Administrative Science Quarterly, 50(3), 329-366.

Baldwin, J. R., \& Hanel, P. (2003). Innovation and knowledge creation in an open economy: Canadian industry and international implications. Cambridge: Cambridge University Press.

Baumann, J., \& Kritikos, A. S. (2016). The link between R\&D, innovation and productivity: Are micro firms different? Research Policy, 45(6), 1263-1274.

Becheikh, N., Landry, R., \& Amara, N. (2006). Lessons from innovation empirical studies in the manufacturing sector: A systematic review of the literature from 19932003. Technovation, 26(5-6), 644-664.

Benavente, J. M. (2006). The role of research and innovation in promoting productivity in Chile. Economics of Innovation and New Technology, 15(4-5), 301-315.

Benavente, J., \& Bravo, C. (2009). Innovation, R\&D investment and productivity in Latin American and Caribbean firms: The Chilean case. Washington, DC: Latin American and Caribbean Research Network, Inter-American Development Bank.

Bergh, D. D., Sharp, B. M., Aguinis, H., \& Li, M. (2017). Is there a credibility crisis in strategic management research? Evidence on the reproducibility of study findings. Strategic Organization, 15(3), 423-436.

Bettis, R. A., Helfat, C.E., \& Shaver, J.M. (2016). The necessity, logic, and forms of replication. Strategic Management Journal, 37(11), 2193-2203.

Bogliacini, F., Perani, G., Pianta, M., \& Supino, S. (2012). Innovation and development: The evidence from innovation surveys. Latin American Business Review, 13(3), 219-261.

Chudnovsky, D., López, A., \& Pupato, G. (2006). Innovation and productivity in developing countries: A study of Argentine manufacturing firms' behavior (1992-2001). Research Policy, 35(2), 266-288.

CIEM, DoE, ILSSA, and UNU-WIDER (2008). Report: Characteristics of the Vietnamese business environment: Evidence from an SME survey in 2007. Hanoi: Central Institute for Economic Management. 
CIEM, DoE, ILSSA, and UNU-WIDER (2010). Report: Characteristics of the Vietnamese business environment: Evidence from an SME survey in 2009. Hanoi: Central Institute for Economic Management.

CIEM, DoE, ILSSA, and UNU-WIDER (2012). Report: Characteristics of the Vietnamese business environment: Evidence from an SME survey in 2011. Hanoi: Central Institute for Economic Management.

CIEM, DoE, ILSSA, and UNU-WIDER (2014). Report: Characteristics of the Vietnamese business environment: Evidence from an SME survey in 2003. Hanoi: Central Institute for Economic Management.

Cohen, W. M., \& Levinthal, D. A. (1989). Innovation and learning: The two faces of R\&D. The Economic Journal, 99(397), 569-596.

Correa, P., Sánchez, I. G., \& Singh, H. (2005). Research, innovation and productivity: Firm level analysis for Brazil. Mimeographed document.

Crépon, B., Duguet, E., \& Mairesse, J. (1998). Research, innovation and productivity: An econometric analysis at the firm level. Economics of Innovation and New Technology, 7(2), 115-158.

Crespi, G., \& Zuniga, P. (2012). Innovation and productivity: Evidence from six Latin American countries. World Development, 40(2), 273-290.

Criscuolo, C. (2009). Innovation and productivity: Estimating the core model across 18 countries. In OECD (ed.), Innovation in firms: A microeconomic perspective. Paris: OECD Publishing.

De Negri, J. A., Esteves, L., \& Freitas, F. (2007). Knowledge production and firm growth in Brazil. Micro Evidence on Innovation in Developing Economies Conference, Maastricht.

Eisenhardt, K. M., \& Martin, J. A. (2000). Dynamic capabilities: What are they? Strategic Management Journal, 21(10-11), 1105-1121.

Filippetti, A., \& Archibugi, D. (2011). Innovation in times of crisis: National systems of innovation, structure, and demand. Research Policy, 40(2), 179-192.

Fréchet, M., \& Goy, H. (2017). Does strategy formalization foster innovation? Evidence from a French sample of small to medium-sized enterprises.M@n@gement,20(3),266-286.

Freel, M. S. (2005). Patterns of innovation and skills in small firms. Technovation, 25(2), 123-134.

Freeman, C., \& Soete, L. (2009). Developing science, technology and innovation indicators: What we can learn from the past. Research policy, 38(4), 583-589.

Garcia-Pozo, A., Marchante-Mera, A. J., \& Campos-Soria, J. A. (2018). Innovation, environment, and productivity in the Spanish service sector: An implementation of a CDM structural model. Journal of Cleaner Production, 171, 1049-1057.

Griffith, R., Huergo, E., Mairesse, J., \& Peters, B. (2006). Innovation and productivity across four European countries. Oxford Review of Economic Policy, 22(4), 483-498.

Griffith, R., Redding, S., \& Van Reenen, J. (2004). Mapping the two faces of R\&D: Productivity growth in a panel of OECD industries. Review of Economics and Statistics, 86(4), 883-895.

GSO (General Statistics Office) (2015). Statistical yearbook: 2014. Hanoi: Statistical Publishing House.

GSO (2016). Statistical yearbook: 2015. Hanoi: Statistical Publishing House.

GSO (2017). Statistical yearbook: 2016. Hanoi: Statistical Publishing House. 
Gurca, A., \& Ravishankar, M. N. (2016). A bricolage perspective on technological innovation in emerging markets. IEEE Transactions on Engineering Management, 63(1), 53-66.

Hahn, S. (2010). Competition, comparison, and innovation. Economics Letters, 106(2), 122-124.

Hall, B. H., \& Mairesse, J. (2006). Empirical studies of innovation in the knowledge-driven economy. Economics of Innovation and New Technology, 15(4-5), 289-299.

Hall, B. H., Lotti, F., \& Mairesse, J. (2009). Innovation and productivity in SMEs: Empirical evidence for Italy. Small Business Economics, 33(1), 13-33.

Hall, B. H., Lotti, F., \& Mairesse, J. (2013). Evidence on the impact of R\&D and ICT investments on innovation and productivity in Italian firms. Economics of Innovation and New Technology, 22(3), 300-328

Hausman, J., \& McFadden, D. (1984). Specification tests for the multinomial logit model. Econometrica: Journal of the Econometric Society, 52(5), 1219-1240.

Heckman, J. J. (1979). Sample selection bias as a specification error. Econometrica: Journal of the Econometric Society, 47(1), 153-161.

Hegde, D., \& Shapira, P. (2007). Knowledge, technology trajectories, and innovation in a developing country context: Evidence from a survey of Malaysian firms. International Journal of Technology Management, 40(4), 349-370.

Huergo, E. \& Moreno, L. (2011). Does history matter for the relationship between R\&D, innovation and productivity? Industrial and Corporate Change, 20(5), 1335-1368.

Iammarino, S. (2005). An evolutionary integrated view of regional systems of innovation: Concepts, measures and historical perspectives. European Planning Studies, 13(4), 497-519.

Janz, N., Lööf, H., \&. Peters, B. (2003). Firm level innovation and productivity: Is there a common story across countries? Problems and Perspectives in Management, 2, 1-22.

Jefferson, G. H., Huamao, B., Xiaojing, G., \& Xiaoyun, Y. (2006). R\&D performance in Chinese industry. Economics of Innovation and New Technology, 15(4-5), 345-366.

Kemp, R., Folkeringa, M., De Jong, J., \& Wubben, E. (2003). Innovation and firm performance. Scales Research Reports N200213. Zoetermeer: EIM Business Policy and Research.

Klomp, L., \& Van Leeuwen G. (2001). Linking innovation and firm performance: A new approach. International Journal of Economics of Business, 8(3), 343-364.

Long, J. S., \& Freese, J. (2006). Regression models for categorical dependent variables using Stata. College Station, TX: Stata Press.

Lööf, H., \& Heshmati, A. (2001). On the relationship between innovation and performance: A sensitivity analysis. SSE/EFI Working Paper Series in Economics and Finance 446. Stockholm: Stockholm School of Economics.

Lööf, H., \& Heshmati, A. (2002). Knowledge capital and performance heterogeneity: A firm-level innovation study. International Journal of Production Economics, 76(1), 61-85.

Lööf, H., \& Heshmati, A. (2006). On the relationship between innovation and performance: A sensitivity analysis. Economics of Innovation and New Technology, 15(4-5), 317-344.

Lööf, H., Heshmati, A., Asplund, R., \& Nåås, S. O. (2001). Innovation and performance in manufacturing industries: A comparison of the Nordic countries. SSE/EFI Working Paper Series in Economics and Finance 457. Stockholm: Stockholm School of Economics. 
Mairesse, J., \& Robin, S. (2008). Innovation and productivity in France: A firm-level analysis for manufacturing and services (1998-2000 and 2002-2004). Symposium on innovation at firm level, Faculty of Economics and Management, University of Barcelona, Barcelona, 1 July.

Mairesse, J., Mohnen, P., Kremp, E., \& Kremp, E. (2005). The importance of R\&D and innovation for productivity: A reexamination in light of the French innovation survey. Annales d'Economie et de Statistique, 79/80, 487-527.

Mairesse, J., Mohnen, P., Zhao, Y., \& Zhen, F. (2012). Globalization, innovation and productivity in manufacturing firms: A study of four sectors of China. ERIA discussion paper 10. Jakarta: Economic Research Institute for ASEAN and East Asia.

Marin, G. (2014). Do eco-innovations harm productivity growth through crowding out? Results of an extended CDM model for Italy. Research Policy, 43(2), 301-317.

Matusik, S. F., \& Heeley, M. B. (2005). Absorptive capacity in the software industry: Identifying dimensions that affect knowledge and knowledge creation activities. Journal of Management, 31(4), 549-572.

McFadden, D. L. (1976). Quantal choice analysis: A survey. In S. V. Berg (ed.), Annals of economic and social measurement, volume 5, number 4. Cambridge, MA: National Bureau of Economic Research (NBER).

Mohnen, P., \& Röller, L. H. (2005). Complementarities in innovation policy. European Economic Review, 49(6), 1431-1450.

Navarro, J. C., Llisterri, J. J., \& Zuñiga, P. (2010). The importance of ideas: Innovation and productivity in Latin America. In: C. Pagés (ed.), The age of productivity: Transforming economies from the bottom up. Development in the Americas report. Washington, DC: Inter-American Development Bank/Palgrave-Macmillan.

Nooteboom, B. (1994). Innovation and diffusion in small firms: Theory and evidence. Small Business Economics, 6(5), 327-347.

OECD (1993). The measurement of scientific and technological activities: Standard practice for surveys of research and experimental development_Frascati Manual 1993. Paris: OECD.

OECD (2001). The OECD productivity manual. Paris: OECD.

Paunov, C. (2012). The global crisis and firms' investments in innovation. Research Policy, 41(1), 24 35.

Pérez, P., Dutrenit, G., \& Barceinas, F. (2005). Innovation activity and economic performance: An econometric analysis of the Mexican case. In M. Albornoz and D. Ratto (eds.), Indicatores de ciencia y tecnología en Iberoamerica: Agenda 2005. Buenos Aires: Indicators of Science and Technology.

Raffo, J., Lhuillery, S., \& Miotti, L. (2008). Northern and southern innovativity: A comparison across European and Latin American countries. The European Journal of Development Research, 20(2), 219-239.

Roper, S., Du, J., \& Love, J. H. (2008). Modelling the innovation value chain. Research Policy, 37(6), 961-977.

Salomon, R. M., \& Shaver, J. M. (2005). Learning by exporting: New insights from examining firm innovation. Journal of Economics \& Management Strategy, 14(2), 431-460.

Santos, D. F. L., Basso, L. F. C., Kimura, H., \& Kayo, E. K. (2014). Innovation efforts and performances of Brazilian firms. Journal of Business Research, 67(4), 527-535. 
Savignac, F. (2008). Impact of financial constraints on innovation: What can be learned from a direct measure? Economics of Innovation and New Technology, 17(6), 553-569.

Schumpeter, J. A. (1934). The theory of economic development: An inquiry into profits, capital, credit, interest, and the business cycle (vol. 55). Cambridge, MA: Harvard University Press.

Schumpeter, J. A. (1942). Socialism, capitalism and democracy. New York: Harper and Brothers.

Senyard, J., Baker, T., Steffens, P., \& Davidsson, P. (2014). Bricolage as a path to innovativeness for resource-constrained new firms. Journal of Product Innovation Management, 31(2), 211-230.

Small, K. A., \& Hsiao, C. (1985). Multinomial logit specification tests. International Economic Review, 26(3), 619-627.

Stoevsky, G. (2005). Innovation and business performance of Bulgarian companies (structural econometric analysis at firm level). Economic Research and Projections Directorate Working Paper. Sofia: Bulgarian National Bank.

Talke, K., Salomo, S., \& Rost, K. (2010). How top management team diversity affects innovativeness and performance via the strategic choice to focus on innovation fields. Research Policy, 39(7), 907-918.

Tsou, M. W., Liu, J. T., Hammitt, J. K., \& Wang, K. H. (2008). Exporting and productivity growth: Evidence from the Taiwan electronics plants. Scottish Journal of Political Economy, 55(2), 190_ 209.

Van de Ven, A. H. (1986). Central problems in the management of innovation. Management science, 32(5), 590-607.

Vivarelli, M. (2014). Innovation, employment and skills in advanced and developing countries: A survey of economic literature. Journal of Economic Issues, 48(1), 123-154.

Wadho, W., \& Chaudhry, A. (2018). Innovation and firm performance in developing countries: The case of Pakistani textile and apparel manufacturers. Research Policy, 47(7), 1283-1294. 